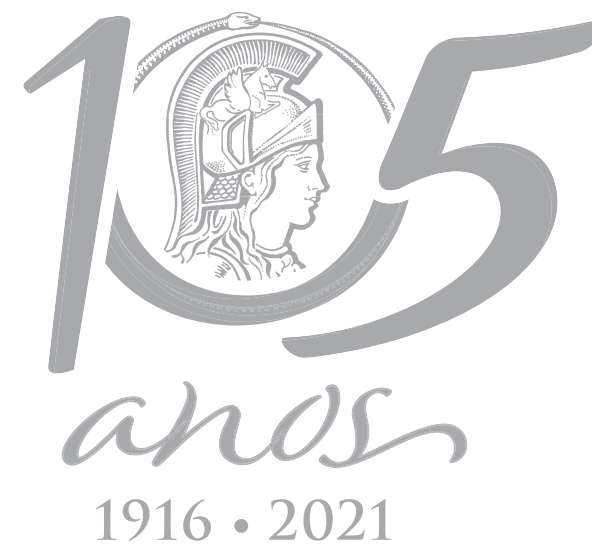

$1916 \cdot 2021$

\title{
MICROBIOLOGY
}

\section{Characterization of the antimicrobial activity produced by Bacillus sp. isolated from wetland sediment}

\author{
LUCIANI CAVALINI, PRISCILA JANKOSKI, ANA PAULA F. CORREA, ADRIANO \\ BRANDELLI \& AMANDA S. DA MOTTA
}

\begin{abstract}
Bacteria of the genus Bacillus sp. present the potential for inhibiting various pathogens, making them a promising starting point in the search for new antimicrobial substances. In this study, bacteria were isolated from sediment samples from humid areas of a Natural Conservation Unit in the state of Rio Grande do Sul, Brazil. The isolate Bacillus sp. sed 1.4 was selected for production of antimicrobial activity, and was characterized by MALDI-TOF and 16S rDNA sequencing. Phylogenetic analysis showed that Bacillus sed 1.4 was closely related to Bacillus altitudinis and Bacillus pumilus. The cell-free supernatant was partially purified using ammonium sulfate precipitation, gel filtration chromatography (Sephadex G-200) and an ultrafiltration membrane. Partial purification resulted in specific activity of $769.23 \mathrm{AU} / \mathrm{mg}$, with a molecular mass of approximately $148 \mathrm{kDa}$. This antimicrobial substance showed stability at $100^{\circ} \mathrm{C}$ for 5 $\mathrm{min}$, and was inactivated by proteolytic enzymes. An antimicrobial effect against Listeria species was observed. Considering the importance of the Listeria genus in the area of food safety, this antimicrobial activity should be further explored, specifically in the field of dairy products and with a focus on food biopreservation studies.
\end{abstract}

Key words: food conservation, Listeria sp., wetland sediments, bioactive substances.

\section{INTRODUCTION}

In recent decades, new challenges have arisen for the pharmaceutical and food industries regarding the fight against pathogenic microorganisms and spoilage. In the clinical area, the challenges are even greater due to the emergence of antimicrobial resistance, which due to selective pressure, causes microorganisms to no longer respond to the usual antimicrobial drugs (Devatkal et al. 2014, Choi et al. 2019). In this view, exploring new antimicrobial substances has become an object of intensive investigation. The sporulation and rapid growth, which are characteristic of the genus Bacillus, mean significant advantages in terms of survival in different habitats. This is also the reason for the research on their ability to produce bioactive substances (Ebrahimipour et al. 2014, Dimkic et al. 2017, Beltran et al. 2018, Zhao et al. 2018). Bacillus also has industrial applications due to its easy genetic manipulation, favorable cultivation characteristics on a large scale and the ability to secrete GRAS status proteins ("Generally Recognized As Safe") (Zhang et al. 2020).

Bacillus can produce a diversity of antimicrobial substances, including several antimicrobial peptides (Gebhardt et al. 2002, Stein 2005). Bacteriocins, for example, are antimicrobial peptides that can potentially be used as food preservatives. Nisin, produced 
by Lactococcus lactis, is a bacteriocin that has granted a safe status and has been approved for use as natural food preservative in several countries (Garsa et al. 2014, Bali et al. 2016).

Other studies have shown that antimicrobial lipopetides produced by Bacillus also present relevant inhibitory properties. Surfactin can reduce Salmonella enterica and Legionella pneumophila biofilm formation in urinary catheters. The extract obtained from the Bacillus subtilis l1a strain exhibited an inhibitory effect against planktonic and sessile forms of E. coli, Serratia marcescens, Enterobacter cloacae, Proteus mirabilis, Citrobacter freundii and E. faecalis (Bernat et al. 2016).

It is important to highlight that environments such as soil and sediment, due to the multiplicity of metabolic activities they accommodate, are viable and sustainable paths for the isolation of microorganisms and the obtaining of new antimicrobial compounds (Zhou et al. 2017, Quintero et al. 2018). Thus, the objective of this research was to characterize a substance produced by a bacterium isolated sediment samples from a conservation unit(CU) in southern Brazil in order to verify its antimicrobial activity against clinical and foodborne pathogens.

\section{MATERIALS AND METHODS}

\section{Identification of the microorganism}

The bacterial isolate was obtained from sediment samples from the wetlands of a Conservation Unit (CU), at a park called the Parque Natural Municipal Imperatriz Leopoldina (S 29045'374") W 5107'992), located in São Leopoldo, Brazil (unpublished data). For identification, the isolate was subjected to analysis by Matrix Associated Laser Desorption-Ionization - Time of Flight (Bruker MALDI-TOF/MS system), MALDI-TOF Biotyper (software v 4.0). From the identification results, a dendrogram was constructed through
Principal Component Analysis (PCA). The identification of the bacteria was also performed through the amplification and sequencing of 16S rDNA, run on a Thermal Cycler model 2720 (Applied Biosystems by Life Technologies ${ }^{\circledR}$ ). Primers FC27 (5'-AGAGTTTGATCCTGGCTCAG-3') and R530 (5' - CCGCGGCTGCTGGCACGTA - 3') were used (Gontang et al. 2007). The PCR was run for $5 \mathrm{~min}$ at $94^{\circ} \mathrm{C}$ followed by 35 cycles of 1 min at $95^{\circ} \mathrm{C}$, $1 \mathrm{~min}$ at $58{ }^{\circ} \mathrm{C}$ and $1 \mathrm{~min}$ at $72{ }^{\circ} \mathrm{C}$, with a final extension of $10 \mathrm{~min}$ at $72^{\circ} \mathrm{C}$. The sequencing of the samples was performed at the ACTGene Análises Moleculares Ltda company (Porto Alegre, Brazil). The AB 3500 Genetic Analyzer automated sequencer (Applied Biosystems) was used. Sequencing data were collected with the Data Collection 2 program (Applied Biosystems). Results were analyzed using the Chrome program version 2.6.4 (Technelysium Pty Ltd) and compared to the National Center for Biotechnology Information (NCBI) database (https://www.ncbi.nlm.nih.gov/). The construction of the phylogenetic tree was performed using the MEGAX software.

\section{Growth curve and production of the antimicrobial substance}

The microorganism was cultivated in tryptic soy broth (Kasvi) at $30^{\circ} \mathrm{C}$ for $48 \mathrm{~h}$ in an orbital shaking incubator at $50 \mathrm{rpm}$. Aliquots were taken at regular 2-h intervals and evaluated for bacterial growth, which was expressed as colonyforming units per milliliter (CFU/ml) (Miles et al. 1938). The production of the antimicrobial substance was determined by the serial dilution method to measure activity units per milliliter (AU/ml) (Motta \& Brandelli 2002). The $\mathrm{pH}$ of the culture was evaluated in triplicate using a $\mathrm{pH}$ meter (DM-22A Digimed). 


\section{Partial purification of the antimicrobial substance}

After cultivation, precipitation with ammonium sulfate at 0-60\% was performed according to Scopes (1994). The precipitated material was suspended in $10 \mathrm{mM}$ sodium phosphate buffer pH 6.0, and partially purified by liquid gel-filtration column chromatography (Sephadex G-200) eluted with the same buffer. Fractions were collected and the absorbance at $280 \mathrm{~nm}$ was determined using a spectrophotometer. The antimicrobial activity of the collected fractions was assessed according to Motta \& Brandelli (2002). The fractions presenting antimicrobial activity were fractionated ultrafiltration system, with a $50 \mathrm{kDa}$ retention membrane (Amicon Ultra). The degree of purification of each step was assessed via denaturing polyacrylamide gel electrophoresis (SDS-PAGE) (Laemmli 1970) stained with silver nitrate (Heukeshoven \& Dernick 1985). The protein concentration was determined through the Folin-Ciocalteu reagent method (Lowry et al. 1951).

\section{Characterization of the partially purified substance}

The fractions showing antimicrobial activity were set apart and assessed for maintenance of antimicrobial activity under different conditions. Thermal stability was determined by exposing aliquots in an Eppendorf Microtube with a volume of 1000 $\mu \mathrm{L}$ at $100^{\circ} \mathrm{C}$, in a dry bath, for 3, 5 and $10 \mathrm{~min}$. Aliquots were also exposed to $121^{\circ} \mathrm{C} / 105 \mathrm{kPa}$ for $15 \mathrm{~min}$. To evaluate stability at low temperatures, aliquots were refrigerated at $4^{\circ} \mathrm{C}$ for 10,20 and 30 days and frozen at $-20{ }^{\circ} \mathrm{C}$ for 30 days. To determine sensitivity to the proteolytic enzymes, aliquots were treated at $37{ }^{\circ} \mathrm{C}$ for $60 \mathrm{~min}$ with trypsin and papain $(2 \mathrm{mg} / \mathrm{mL})$, with $10 \mathrm{mM}$ sodium phosphate buffer $\mathrm{pH}$ 6.0.
The chemical stability of the antimicrobial activity against organic solvents and detergents was also tested. To this test, $25 \mu \mathrm{L}$ of the chemicals were added to $50 \mu \mathrm{L}$ of partially purified substance, and incubated for $60 \mathrm{~min}$ at $37{ }^{\circ} \mathrm{C}$. The solvents employed were: acetone (NEON), methanol (DINAMICA), ethanol (NEON), chloroform (ACROS) xylene (Synth), dimethyl sulfoxide (DMSO) (Synth), butanol (NEON) and ethyl ether (ALPHA) at a final concentration of $50 \%(\mathrm{v} / \mathrm{v})$. The detergents used were Tween 20 and Tween 80 at a final concentration of $10 \%$ (v/v) (Motta et al. 2007a). The potential synergistic effects of organic solvents were also investigated in this study. At the end of each treatment, the aliquots were examined to verify antimicrobial activity against the indicator bacteria Listeria monocytogenes ATCC 7644 (Motta \& Brandelli 2002).

\section{Inhibitory spectrum}

The antimicrobial activity was tested against cultures of clinical and food isolates. Suspensions of these indicator cultures were prepared in $0.85 \% \mathrm{NaCl}$, corresponding to 0.5 turbidity on the MacFarland scale (approximately $1.5 \times 10^{8} \mathrm{CFU} / \mathrm{mL}$ ), and spread with a swab on Mueller Hinton agar plates. Twenty $\mu \mathrm{L}$ of the partially purified fractions were applied in duplicate. The plates were incubated for $24 \mathrm{~h}$ at the optimum temperature for each indicator microorganism. The isolates used in the study were Escherichia coli ATCC 25922, Klebsiella pneumoniae ATCC 700603, Salmonella Typhimurium ATCC 14028, Pseudomonas aeruginosa ATCC 27853, Serratia marcescens ATCC 43861, Corynebacterium fimi NCTC 7547, Corynebacterium striatum ATCC BAA 1293, Listeria innocua (CT) 00354 ATCC 33090, Listeria ivanovii 00355 ATCC 19119, Listeria monocytogenes ATCC 7644, Enterococcus faecalis ATCC 29212, Staphylococcus aureus 
ATCC 25923, Staphylococcus saprophyticus ATCC 15305, Staphylococcus epidermidis ATCC 35954, Staphylococcus aureus ATCC 29213, Candida albicans ATCC 90028, Candida parapsilosis ATCC 22019 and Candida krusei ATCC 6258. Microorganisms isolated during the routine of a clinical laboratory (Laboratório de Análises Clínicas de Porto Alegre), as well as foodborne samples collected from the Instituto de Ciências Básicas da Saúde (ICBS) laboratory of Universidade Federal do Rio Grande do Sul, were also used in the evaluation of antimicrobial activity. These include isolates of Escherichia coli, Klebsiella pneumoniae, Enterobacter sp., Pseudomonas aeruginosa, Salmonella sp., Shigella sp., Pseudomonas sp., Acinetobacter baumanni, Staphylococcus sp., Enterobacter sp., and Listeria sp. The inhibition zones formed after the incubation period were measured, and expressed in millimeters $(\mathrm{mm})$.

\section{RESULTS}

\section{Identification of the selected isolate}

The bacterial isolate sed 1.4 was identified at genus level as Bacillus sp. through the MALDI-TOF/MS analysis, considering the score result (score 2.048). The data obtained were used to construct a dendrogram, which is arranged according to the levels of similarity among the phenotypic expression of proteins present in the strains (Figure 1). The comparison was carried out with Bacillus sp. sed 1.4 and Bacillus strains present in the MALDITOF database. Based on Figure 1, it could be suggested that the isolate Bacillus sp. sed 1.4 is more closely related to Bacillus altitudinis, with a distance level near 100, whereas its relationship to Bacillus pumilus is more distant, slightly greater than 100. However, both bacteria share an ancestor with common phenotypic characteristics.
The sequence of the 16S rRNA gene was compared with sequences similar to those of reference microorganisms, using the NCBI Basic Local Alignment Search Tool (BLAST) (www. ncbi.nlm.nich-gov/BLAST). The sequences of the following species were obtained from GenBank: Bacillus pumilus WAPB 4 DQ355508 (AUNPAD \& NA-BANGCHANG 2007), Bacillus altitudinis D70 MK720001, Bacillus altitudinis D164 MK720011, Bacillus pumilus SAFR-032, Bacillus pumilus WAPB4 DQ355508, Bacillus pumilus strain ATCC 7061 NR_043242. Bacillus sp. sed 1.4 showed $75 \%$ similarity with Bacillus altitudinis KJ020347 and Bacillus pumilus NR043242 and 97\% with Bacillus sp. sed 2.2 MH666075. According to the phylogenetictree of the 16SrDNA(Figure2) Bacillus sp. sed 1.4, Bacillus altitudinis and Bacillus pumilus isolates shared $100 \%$ similarity to the grouped 16S rDNA sequence. The phylogenetic tree was built using the NeighborJoining method. The gene sequence of Bacillus sp. sed 1.4 was submitted to Standard Nucleotide BLAST with the access code MH666076 (https://blast.ncbi.nih.gov/).

\section{Growth curve and production of the antimicrobial substance}

The antimicrobial activity production by Bacillus sp. sed 1.4 was observed during the exponential growth phase at $9 \mathrm{~h}$ cultivation. Maximum antimicrobial activity of $200 \mathrm{AU} / \mathrm{mL}$ was reached in the stationary phase, between 12 and $30 \mathrm{~h}$ (Figure 3), followed by a decline to $100 \mathrm{AU} / \mathrm{mL}$ after $33 \mathrm{~h}$ incubation. The indicator bacterium was L. monocytogenes ATCC 7644. After obtaining this result, crude supernatant obtained at $24 \mathrm{~h}$ cultivation was sampled and used for purification steps. The $\mathrm{pH}$ of the culture remained constant (7.0) throughout the incubation period. 


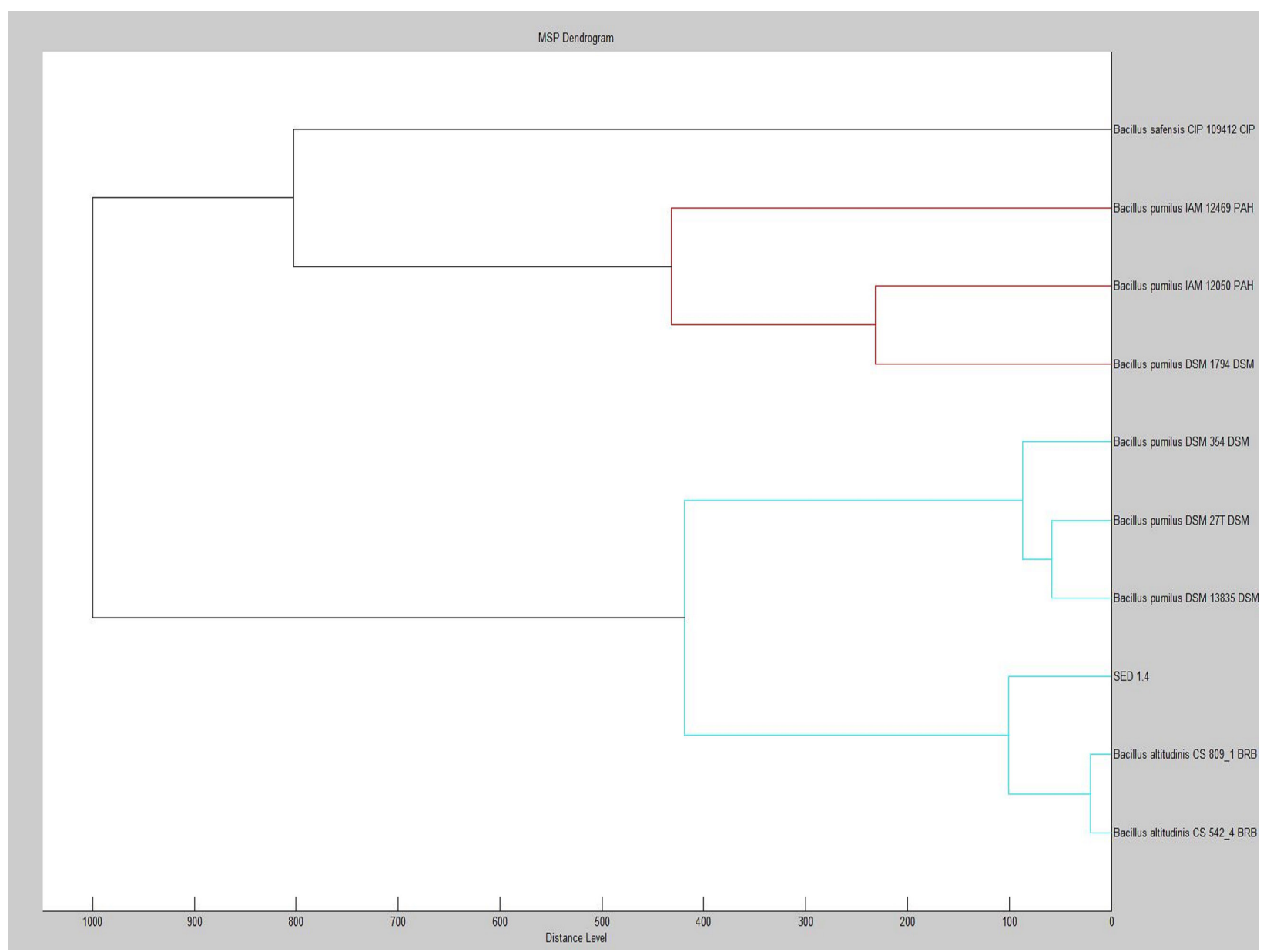

Figure 1. Dendrogram of Bacillus species showing the levels of similarity in the phenotypic expression of proteins present in the isolates.

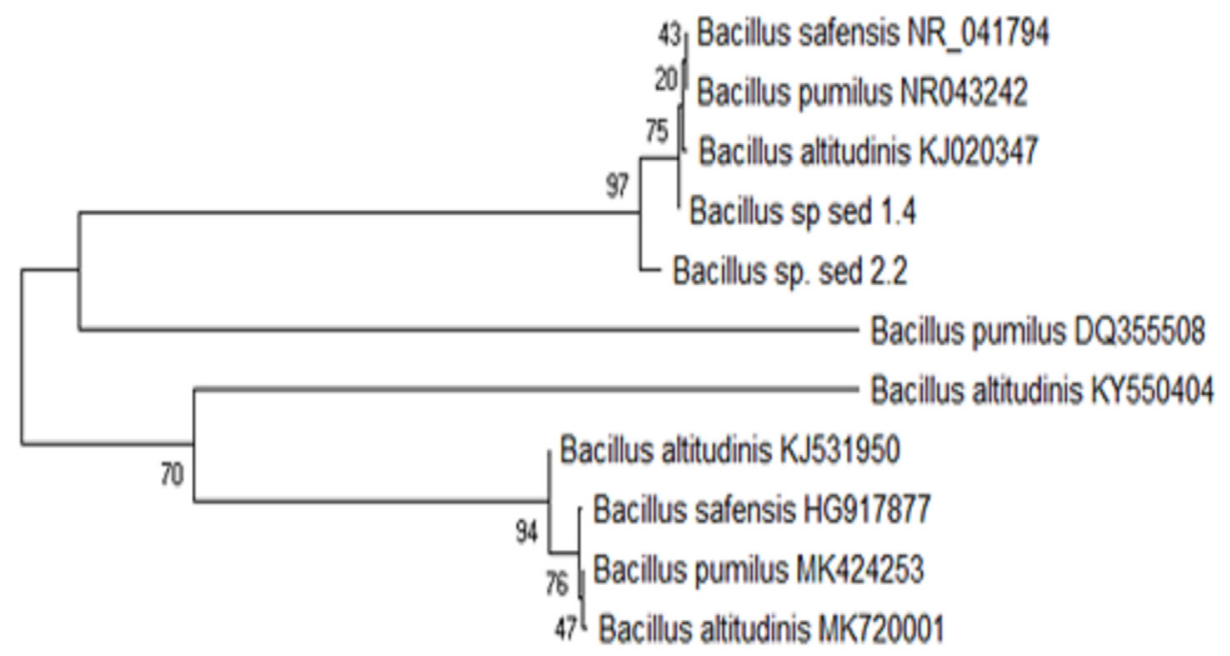

Figure 2. Phylogenetic tree obtained from the 16S rRNA gene of the sequences with closer similarities suggested by BLAST and identified isolates from other studied sediments.

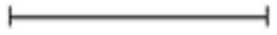




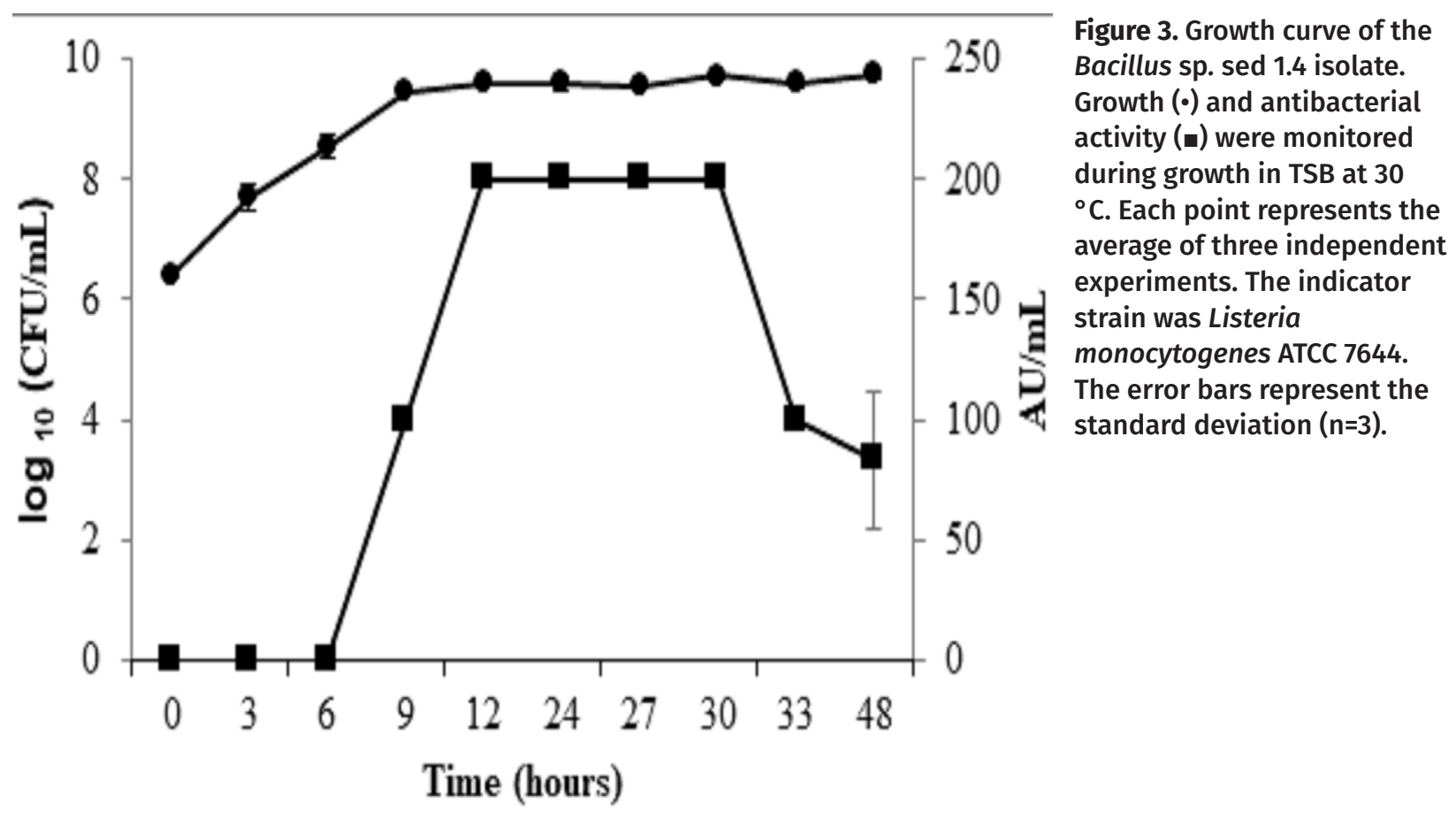

\section{Partial purification of the antimicrobial substance}

The precipitation with ammonium sulfate was carried out with the crude supernatant obtained after $24 \mathrm{~h}$ culture. It was found that the grouped saturation bands (0 to 60\%) reached an activity of $3200 \mathrm{AU} / \mathrm{mL}$ when tested against the indicator strain L. monocytogenes ATCC 7644.

The pellet resulting from precipitation with ammonium sulfate was resuspended with $10 \mathrm{mM}$ sodium phosphate buffer $\mathrm{pH}$ 6.0, and applied to a gel filtration chromatography. Of the 30 fractions collected, fractions 8 and 9 showed antimicrobial activity corresponding to $100 \mathrm{AU} /$ $\mathrm{mL}$ each. Three repetitions were performed and the elution profile was the same.

The fractions exhibiting antimicrobial activity were grouped and subjected to ultrafiltration using membranes with a cut-off molecular weight of $50 \mathrm{kDa}$. In this purification step, activity was observed in the retained fraction, with inhibition zones of $12 \mathrm{~mm}$ on average; while the antimicrobial activity of 100 $\mathrm{AU} / \mathrm{mL}$ was maintained, the filtered fraction did not show antimicrobial activity against the indicator strain L. monocytogenes ATCC 7644.

As seen in Table I, it was noted that the antimicrobial substance showed 22.37 AU/ mg specific activity in the crude supernatant, while the fractions obtained after gel filtration chromatography presented $769.23 \mathrm{AU} / \mathrm{mg}$, with a final yield of $2 \%$. The protein profiles of the crude supernatant, ammonium sulfate precipitate and the antimicrobial substance resulting from gel filtration chromatography, was evaluated by means of polyacrylamide gel electrophoresis (Figure 4). In the polyacrylamide gel, a main band of the active fractions eluted from the Sephadex G-200 column was observed, with a molecular weight of approximately $148 \mathrm{kDa}$.

\section{Characterization of the antimicrobial substance}

In assessing the stability of the studied antimicrobial substance, it was seen that antimicrobial activity was maintained at $100 \%$ when treated at $100{ }^{\circ} \mathrm{C}$ for up to $5 \mathrm{~min}$, but complete inactivation occurred after exposure 
Table I. Concentration of soluble proteins and antimicrobial activity from the fractions resulting from the purification steps, produced by Bacillus sp. sed 1.4.

\begin{tabular}{|c|c|c|c|c|c|c|c|}
\hline Fraction & A & Vol & TA & TProt & S.A. & P.F. & Y \\
\hline Crude & 200 & 299 & 59.800 & 8.94 & 22.37 & 1 & 100 \\
\hline PPT & 3200 & 6 & 19200 & 6.87 & 465.79 & 17.2 & 32.1 \\
\hline Sephadex & 100 & 12 & 1200 & 1.56 & 769.23 & 32.9 & 2.0 \\
\hline
\end{tabular}

PPT- post-precipitation at 0-60\%, A, Activity(AU/ml); Vol, Volume (ml); TA, Total Activity (AU); TProt, Total protein (mg/ml); S. A., Specific activity (UA/mg); P.F., Purification factor; Y, Yield (\%).

for $10 \mathrm{~min}$ at the same temperature, and also at $121^{\circ} \mathrm{C} / 15 \mathrm{~min}$. When refrigerated at $4^{\circ} \mathrm{C}$, it maintained $100 \%$ antimicrobial activity for 10 days, and for 30 days when frozen at -20 ${ }^{\circ} \mathrm{C}$. The antimicrobial substance was completely inactivated when treated with the proteolytic enzymes papain and trypsin.

As for the effects of chemicals and detergents, it can be seen that there was complete inactivation when treated with Tween 80. When antimicrobial stability was tested against acetone, $66 \%$ residual activity was observed and above $80 \%$ when tested with methanol, ethanol, chloroform, xylene, diethyl ether, dimethyl sulfoxide, butanol and Tween 20, as shown in Table II.

\section{Determination of the antimicrobial activity spectrum}

In this evaluation, the antimicrobial substance demonstrated activity against the tested Listeria species, with inhibition zones between 10 and 13 mm (Table III). However, there was no inhibition of gram-negative bacteria, yeasts and other gram-positive species.

\section{DISCUSSION}

The identification of Bacillus sp. sed 1.4 was performed using MALDI-TOF and by sequencing the $16 \mathrm{~S}$ rRNA gene. However, the methodologies were not sufficient for identification at the species level. Although the $16 \mathrm{~S}$ rRNA gene is widely used for the identification of bacteria, it is limited for the genus Bacillus as it contains several groups of closely related species. This can make identification challenging. Bacillus altitudinis, Bacillus stratosphaericus e Bacillus aerophilus and Bacillus pumilus, for example, have very similar sequences of the $16 \mathrm{~S}$ rRNA gene, making it difficult to identify them based on this type of analysis (Starostin et al. 2015). Elbanna et al. (2014), report that B. altitudinis and B. pumilus showed $99 \%$ similarity to each other after having their 16S rRNA gene sequences analyzed. Thus, techniques such as differential PCR of the genes $r p o B$, gyrB, nifD, recA and atpD, have been studied as alternatives in distinguishing among of Bacillus species (Ki et al. 2009, Bhandari et al. 2013, Quintero et al. 2018). For instance, the rpoB gene, which is homogeneous within cells because it is a single-copygene, has relativelylong sequences (approximately $3.5 \mathrm{~kb}$ in Bacillus), and many of these sequences are available in public databases (Ki et al. 2009).

The phylogenetic tree revealed that Bacillus sp. sed 1.4 is related to Bacillus altitudinis KJ020347 and Bacillus pumilus NR 043242, by a similarity of $75 \%$. Additionally, there is a $97 \%$ similarity with Bacillus sp. sed 2.2 MH666075, another isolate from the same Conservation Unit, but collected in a different period. This 


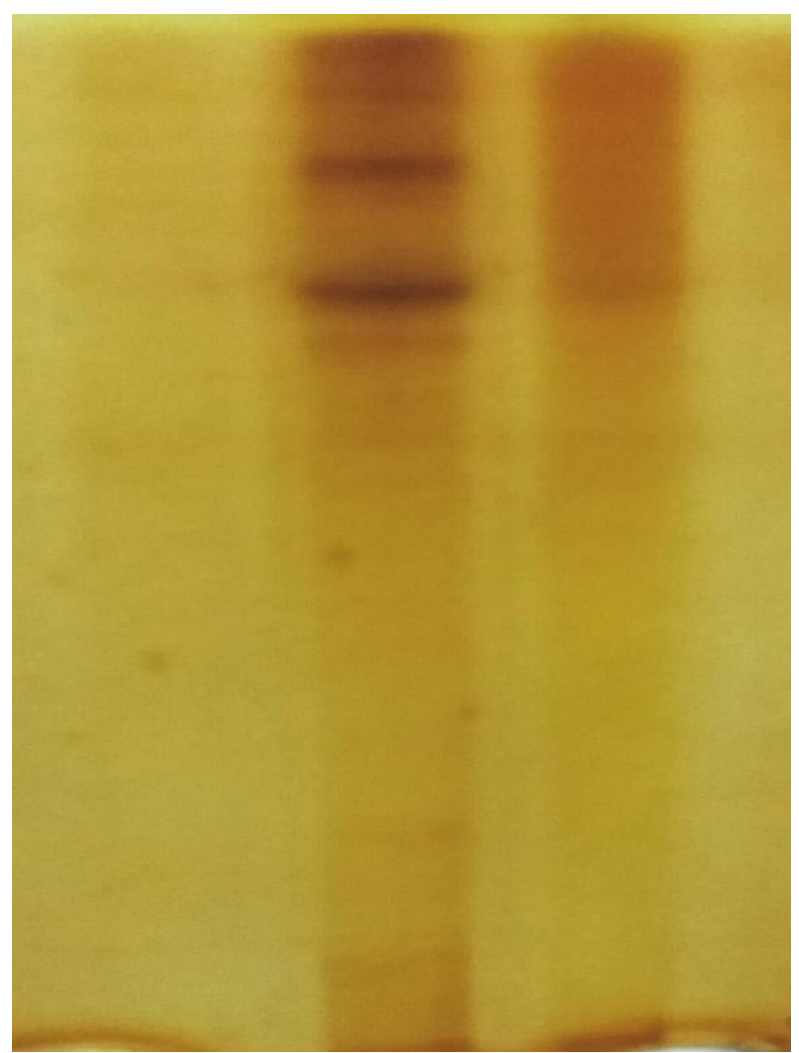

Figure 4. Electrophoresis in polyacrylamide gel stained with silver nitrate showing the protein bands of the stages of partial purification of the antimicrobial substance produced by Bacillus sp. sed 1.4. A: G-200, B: precipitated in the $0-60 \%$ range, $\mathrm{C}$ : crude supernatant, MW: molecular weight marker.

finding confirms the close relationship between species.

Data from MALDI-TOF/MS demonstrate that Bacillus sp. sed 1.4 is closely related to Bacillus altitudinis, with a level of similarity near to 100. The correlation with the species Bacillus pumilus showed a similarity level to the clusters of 400 . Based on the reference database obtained in a comparison of MALDI-TOF data, Starostin et al. (2015) identified bacterial isolates such as Bacillus pumilus and Bacillus altitudinis. The dendrograms also showed that both groups have a similarity level of 400 .

Bacillus sp. sed 1.4 was evaluated for its antimicrobial potential. The antimicrobial substance produced by this isolate demonstrated maximumactivity in thestationary phase between 12 and $30 \mathrm{~h}$, which is characteristic of a secondary metabolite. In a previous study, Boottanun et al. (2017), investigated the production of metabolites with antimicrobial activity secreted by Bacillus amyloliquefaciens. These metabolites were produced early in the incubation period until reaching a steady state between 12 and $72 \mathrm{~h}$. Chalasani et al. (2015) also detected the beginning of antimicrobial substance production at $9 \mathrm{~h}$ cultivation, reaching a maximum production at $40 \mathrm{~h}$. The activity of some secondary metabolites decreases when the producing bacteria enter the stationary phase, due to the adsorption of molecules on the surface of the producing cells and proteolytic degradation (Guo et al. 2012, Chikindas et al. 2018).

The antimicrobial substance produced by Bacillus sp. sed 1.4 was partially purified using precipitation with ammonium sulfate at $0-60 \%$ saturation, gel filtration chromatography and an ultrafiltration membrane. The antimicrobial substance has an apparent molecular mass greater than $50 \mathrm{kDa}$, as it was retained in the ultrafiltration membrane and showed approximately $148 \mathrm{kDa}$ during electrophoresis, which is included in the fractionation range of the Sephadex G-200 resin (5 to 600 kDa). According to the literature, the antimicrobial substances produced by Bacillus are generally small, showing molecular weight below 30 kDa (Zhao et al. 2018). Antimicrobial peptides produced by Bacillus spp. evaluated by denaturing polyacrylamide gel electrophoresis often shown a molecular weight of approximately $3 \mathrm{kDa}$ or less (Chalasani et al. 2015, Regmi et al. 2017). However, the large molecular weight observed in this study may suggest that the substance is secreted in the form of aggregates. This corroborates findings described by Cladera-Olivera et al. (2004), in which Bacillus licheniformis $\mathrm{P} 40$ produced 
Table II. Effect of different chemicals and organic solvents on the antimicrobial activity of the partially purified crude supernatant produced by Bacillus sp. sed 1.4.

\begin{tabular}{|c|c|c|c|}
\hline Treatment & Concentration & Residual activity (\%) & Standard deviation \\
\hline Acetone & $50 \%(\mathrm{v} / \mathrm{v})$ & 66 & 4 \\
\hline Methanol & $50 \%(\mathrm{v} / \mathrm{v})$ & 100 & 6 \\
\hline Ethanol & $50 \%(\mathrm{v} / \mathrm{v})$ & 87.5 & 2.25 \\
\hline Chloroform & $50 \%(\mathrm{v} / \mathrm{v})$ & 87.5 & 0.5 \\
\hline Xylene & $50 \%(\mathrm{v} / \mathrm{v})$ & 100 & 1 \\
\hline DMSO & $50 \%(\mathrm{v} / \mathrm{v})$ & 91.66 & 1 \\
\hline Ethyl ether & $50 \%(\mathrm{v} / \mathrm{v})$ & 87.5 & 2.81 \\
\hline Butanol & $50 \%(\mathrm{v} / \mathrm{v})$ & 100 & 6 \\
\hline Tween 20 & $10 \%(\mathrm{v} / \mathrm{v})$ & 141.66 & 1 \\
\hline Tween 80 & $10 \%(\mathrm{v} / \mathrm{v})$ & 0 & 0 \\
\hline
\end{tabular}

Tests were performed by incubating the partially purified crude supernatant and treating it at 37-C for $1 \mathrm{~h}$. Residual activity was estimated against Listeria monocytogenes ATCC 7644.

an antimicrobial substance of approximately $150 \mathrm{kDa}$ when the sample was eluted using Sephadex G-100. These results are also similar to those reported for the bacteriocin Linocin M18 (Valdés-Stauber \& Scherer 1994). It has been suggested that the association of molecules in large aggregates is possibly due to the highly hydrophobic nature of the peptides.

Motta et al. (2007b) demonstrate the effects of a peptide produced by Bacillus P34 on the growth of Listeria monocytogenes and Bacillus cereus with antimicrobial activity of $160 \mathrm{AU} / \mathrm{mL}$ over a period of $24 \mathrm{~h}$. At the end of the partial purification process, the fraction was purified 32.9 times with a yield of $2 \%$ and specific activity of $769.23 \mathrm{AU} / \mathrm{mg}$. A protease produced by Bacillus cereus was purified by chromatographic precipitation techniques with ammonium sulfate (50\%), ion exchange (DEAECellulose) and filtration gel (Sephadex G-100) by Lakshmi et al. (2018), resulting in a protein with specific activity of $300 \mathrm{AU} / \mathrm{mg}$ and recovery of 34.6\%. Mothe \& Sultanpuram (2016) purified an enzyme produced by a new species Bacillus caseinilyticus and it was found that purification using DEAE cellulose column chromatography increased purity by 20.74 times, with specific activity of $89.2 \mathrm{AU} / \mathrm{mg}$.

The effects of proteolytic enzymes, thermal treatments and organic solvents and detergents on the antimicrobial substance produced by Bacillus sp. sed 1.4 suggest that the substance has a protein nature (Sharma et al. 2018, Aunpad \& Nabangchang 2007) The trypsin cleavage site is highly specific, cleaving the peptide bond after residues with long positively charged side chains, such as arginine and lysine, while papain presents broad specificity, cleaving peptide bonds of basic amino acids, leucine, or glycine (Sangeetha \& Abraham 2006, Berg et al. 2014). Antimicrobial peptides that are notsensitive to trypsin probably do not have a lytic site for this protease; nevertheless, inactivation by pancreatic proteases such as trypsin is 
Table III. Spectrum of action of the partially purified antimicrobial substance according to the inhibition zone (mm).

\begin{tabular}{|c|c|}
\hline Indicator microorganism & Inhibition zone (mm) \\
\hline Listeria monocytogenes ATCC 7644 & 12 \\
\hline Listeria monocytogenes 4B (carcass) & 11 \\
\hline Listeria innocua L 10 (buffalo milk) & 11 \\
\hline Listeria monocytogenes QF Oxford (sliced cheese) & 10 \\
\hline Listeria seeligeri BQ Oxford (countertop) & 11 \\
\hline Listeria seeligeri BP Palcam - 2 (countertop) & 13 \\
\hline Listeria seeligeri PF Oxford (sliced ham) & 10 \\
\hline Listeria seeligeri MP Oxford (hands) & 11 \\
\hline Listeria seeligeri BP Oxford (countertop) & 12 \\
\hline
\end{tabular}

interesting in terms of food safety since it does not have the ability to promote changes in the gastrointestinal tract. Some antimicrobial peptides produced by Bacillus spp. are sensitive to trypsin and papain, such as NS02 (Senbagam et al. 2013), trypsin-sensitive N2-4 (Boottanun et al. 2017) and trypsin-sensitive RX7 (Lim et al. 2016). Previous work also described similar results for antimicrobial peptides from Bacillus that were sensitive to trypsin and pronase $\mathrm{E}$ (Motta et al. 2007a), while Lisboa et al. (2006) verified the sensitivity of the antimicrobial substance produced by $B$. amyloliquefaciens the proteolytic enzymes papain and trypsin.

The stability of the antimicrobial substance to thermal treatments, organic solvents and detergents, resembled those observed for some antimicrobial compounds of peptide nature produced by Bacillus spp. (Motta et al. 2007b, Ebrahiumipour 2014, Chalasani et al. 2015, Lee \& Chang 2018).

While the studied substance inhibited the growth of different species of Listeria, it was not able to inhibit Gram-negative bacteria, yeasts and the other Gram-positive species tested, demonstrating a more restricted spectrum of activity. According to Liu (2015), antimicrobial substances produced by Grampositive bacteria have less potential to inhibit the growth of gram-negative bacteria. This is due to the fact that Gram-negative bacteria have an outer membrane, which functions as an impermeable barrier for the cell, making it difficult for antimicrobial peptides to reach the cytoplasmic membrane (Garcia-Gutierrez et al. 2019).

The antimicrobial peptide studied by Lee \& Chang (2018) was tested against a range of Gram-positive and Gram-negative bacteria, and the results obtained showed that the substance was able to inhibit the growth of Gram-positive bacteria such as Bacillus cereus and Listeria monocytogenes. Torres et al. (2015) also found antimicrobial activity against strains of Listeria monocytogenes. In view of the results presented, it is suggested that the substance may be a class Ila bacteriocin, an anti-Listeria type bacteriocin.

Although foodborne disease associated with L. monocytogenes is not as common as those of Salmonella, Campylobacter or Escherichia coli, the mortality rate can be considered the highest. Approximately $30 \%$ of invasive listeriosis cases end in death, and therefore L. monocytogenes can be considered a pathogen 
of food and public health importance (Haggerty et al. 2018, Gray et al. 2018). Often introduced into the processing environment through raw foods, Listeria species can adhere to a variety of surfaces, with some strains persisting for several years and acting as a source of continuous crosscontamination (Colagiorgi et al. 2017, Gray et al. 2018). L. monocytogenes is a difficult organism to eradicate and its presence still occurs despite the best management practices, such as cleaning and sanitizing after contact with food and sterilizing non-food contact surfaces, in addition to equipment maintenance (Drew \& Clydesdale 2015). Thus, the search for alternative antimicrobial substances to control strains of $L$. monocytogenes is a point of great interest (Leite et al. 2016). Based on the results of this work, the substance produced by Bacillus sp. sed 1.4 presented the potential for application in food preservation, as it inhibited all Listeria species tested.

\section{REFERENCES}

AUNPAD R \& NA-BANGCHANG K. 2007. Pumilicin 4, a novel bacteriocin with anti-MRSA and anti-VRE activity produced by newly isolated bacteria Bacillus pumilus strain WAPB4. Curr Microbiol 55(4): 308-313.

BALI V, PANESAR OS, BERA MB \& KENNEDY JF. 2016. Bacteriocins: Recent Trends and Potential Applications. Crit Rev Food Sci Nutr 56(5): 817-834.

BELTRAN JA, AGUILERA-MENDOZA L \& BRIZUELA CA. 2018. Optimal selection of molecular descriptors for antimicrobial peptides classification: an evolutionary feature weighting approach. BMC Genomics 19(7): 672.

BERG JM, STRYER L \& TYMOCZKO JL. 2014. Bioquímica, 7a ed. Rio de Janeiro: Guanabara Koogan.

BERNAT P, PARASZKIEWICZ K, SIEWIERA P, MORYL M, PŁAZA G \& HOJNIAK J. 2016. Lipid composition in a strain of Bacillus subtilis, a producer of iturin A lipopeptides that are active against uropathogenic bacteria. World J Microbiol Biotechnol 32(10): 157.
BHANDARI V, AHMOD Z, SHAH HN \& GUPTA S. 2013. Molecular signatures for Bacillus species: demarcation of the Bacillus subtilis and Bacillus cereus clades in molecular terms and proposal to limit the placement of new species into the genus Bacillus. Int J Syst Evol Microbiol 63: $2712-2726$.

BOOTTANUN P, POTISAP C, HURDLE JG \& SERMSWAN HR. 2017. Secondary metabolites from Bacillus amyloliquefaciens isolated from soil can kill Burkholderia pseudomallei. AMB Express 7(1): 16.

CHALASANI AG, DHANARAJAN G, NEMA S, SEN R \& ROY U. 2015. An Antimicrobial Metabolite from Bacillus sp.: Significant Activity against Pathogenic Bacteria Including MultidrugResistant Clinical Strains. Front Microbiol 6: 1335.

CHIKINDAS ML, WEEKS R, DRIDER D, CHISTYAKOV VA \& DICKS LM. 2018. Functions and emerging applications of bacteriocins. Curr Opin Biotechnol 49: 23-28.

CHOI JH, KIM N, KIM GW \& CHOI HY. 2019. Effect of Cacao Nip Extracts (CEs) on Quality Characteristics of Pork Patties during Cold Storage Period. Food Sci Anim Resour 39(6): 918-933.

CLADERA-OLIVERA F, CARON GR \& BRANDELLI A. 2004 Bacteriocin-like substance production by Bacillus licheniformis strain P40. Lett Appl Microbiol 38: 251-256.

COLAGIORGI A, BRUINI I, DI CICCIO PA, ZANARDI E, GHIDINI S \& IANIERI A. 2017. Listeria monocytogenes Biofilms in the Wonderland of Food Industry. Pathogens 6(3): 41.

DEVATKAL SK, THORAT P \& MANJUNATHA M. 2014. Effect of vacuum packaging and pomegranate peel extract on quality aspects of ground goat meat and nuggets. I Food Sci Technol. 51: 2685-2691.

DIMKIĆ I, STANKOVIĆ S, NIŠAVIĆ M, PETKOVIĆ M, RISTIVOJEVIĆ P, FIRA D \& BERIĆ T. 2017. The Profile and Antimicrobial Activity of Bacillus Lipopeptide Extracts of Five Potential Biocontrol Strains. Front Microbiol 8: 925.

DREW CA \& CLYDESDALE FM. 2015. New food safety law: effectiveness on the ground. Crit Rev Food Sci Nutr 55(5):689-700.

EBRAHIMIPOUR GH, KHOSRAVIBABADI Z, SADEGHI H \& ALIAHMADI A. 2014. Isolation, Partial Purification and Characterization of an Antimicrobial Compound, Produced by Bacillus atrophaeus. Jundishapur J Microbiol 7(9): e11802.

ELBANNA K, ELNAGGAR S \& BAKEER A. 2014. Characterization of Bacillus altitudinis as a new causative agent of bacterial soft rot. J Phytopathol 162: 712-722. 
GARCIA-GUTIERREZ E, MAYER MJ, COTTER PD \& NARBAD A. 2019. Gut microbiota as a source of novel antimicrobials. Gut Microbes 10(1): 1-21.

GARSA AK, KUMARIYA R, SOOD SK, KUMAR A \& KAPILA S. 2014. Bacteriocin production and different strategies for their recovery and purification. Probiotics Antimicrob Proteins 6(1):47-58.

GEBHARDT K ET AL. 2002. Screening for biologically active metabolites with endosymbiotic bacilli isolated from arthropods. FEMS Microbiol. Lett. 217(2): 199-205.

GRAY JA, CHANDRY PS, KAUR M, KOCHARUNCHITT C, BOWMAN JP \& FOX EM. 2018. Novel Biocontrol Methods for. Front Microbiol 9: 605.

GONTANG EA, FENICAL W \& JENSEN PR. 2007. Phylogenetic diversity of gram-positive bacteria cultured from marine sediments. Appl Environ Microbiol 73(10): 3272-3282.

GUO Y, ZHANQIAO Y, JIANHUA X \& RIJUN Z. 2012. Identification of a New Bacillus licheniformis Strain Producing a Bacteriocin-Like Substance. Int J Microbiol 50: 452-458.

HAGGERTY P, SIMMS B, KULLA B \& SHEEHAN J. 2018. Listeria meningoencephalitis and hydrocephalus complicating alemtuzumab therapy for multiple sclerosis-the first reported case in North America. SOJ Microbiol Infect Dis 6(1): 1-5.

HEUKESHOVEN J \& DERNICK R. 1985, Simplified method for silver staining of proteins in polyacrylamide gels and the mechanism of silver staining. Electrophoresis Wiley Online Library 6: 103-112.

KI JS, ZHANG W \& QIAN PY. 2009. Discovery of marine Bacillus species by $16 \mathrm{~S}$ rRNA and rpoB comparisons and their usefulness for species identification. J Microbiol Methods 77(1): 48-57.

LAEMMLI UK. 1970. Cleavage of structural proteins during the assembly of the head of bacteriophage T4. Nature 227(5259): 680-685.

LAKSHMI BKM, MUNI KUMAR D \& HEMALATHA KPJ. 2018. Purification and characterization of alkaline protease with novel properties from Bacillus cereus strain S8. J Genet Eng Biotechnol 16(2): 295-304.

LEE SG \& CHANG HC. 2018. Purification and characterization of mejucin, a new bacteriocin produced by Bacillus subtilis SN7. LWT - Food Sci Tech 87: 8-15.

LEITE JA, TULINI FL, REIS-TEIXEIRA FB, RABINOVITCH L, CHAVES JQ, ROSA NG, CABRAL H \& MARTINIS ECP. 2016. Bacteriocinlike inhibitory substances (BLIS) produced by Bacillus cereus: Preliminary characterization and application of partially purified extract containing BLIS for inhibiting
Listeria monocytogenes in pineapple pulp. LWT - Food Sci Tech 72: 261-266.

LIM KB, BALOLONG MP, KIM SH, OH JK, LEE JY \& KANG DK. 2016. Isolation and Characterization of a Broad Spectrum Bacteriocin from Bacillus amyloliquefaciens RX7. BioMed Res Int 2016: 2314-6133.

LISBOA MP, BONATTO D, BIZANI D, HENRIQUES JA \& BRANDELLI A. 2006. Characterization of a bacteriocin-like substance produced by Bacillus amyloliquefaciens isolated from the Brazilian Atlantic forest. Int Microbiol 9(2): 111-118.

LIU X. 2015. Properties of a Bacteriocin Produced by Bacillus subtilis EMD4 Isolated from Ganjang (Soy Sauce). J Microbiol Biotechnol 25(9): 1493-1501.

LOWRY OH, ROSENBROUGH NJ, FARR AL \& RANDALL RJ. 1951. Protein measurement with the phenol reagent. J Biol Chem 193(1): 265-275.

MILES AA, MISRA SS \& IRWIN JO. 1938. The estimation of the bactericidal power of the blood. J Hyg (Lond) 38(6): 732-749.

MOTHE T \& SULTANPURAM VR. 2016. Production, purification and characterization of a thermotolerant alkaline serine protease from a novel species Bacillus caseinilyticus. 3 Biotech 6(1): 53.

MOTTA AS \& BRANDELLI A. 2002. Characterization of an antibacterial peptide produced by Brevibacterium linens. J Appl Microbiol 92: 63-70.

MOTTA AS, CANNAVAN FS, SIU-MUI T \& BRANDELLI A. 2007a. Characterization of a broad range antibacterial substance from a new Bacillus species isolated from Amazon basin. Arch Microbiol 188(4): 367-375.

MOTTA AS, LORENZINI DM \& BRANDELLI A. 2007b. Purification and partial characterization of an antimicrobial peptide produced by a novel Bacillus sp. Isolated from the Amazon Basin. Curr Microbiol 54(4): 282-286.

QUINTERO M, VELÁSQUEZ A, JUTINICO LM, JIMÉNEZ-VERGARA E, BLANDÓN LM, MARTINEZ K, LEE HS \& GÓMEZ-LEÓN J. 2018. Bioprospecting from marine coastal sediments of Colombian Caribbean: screening and study of antimicrobial activity. J Appl Microbiol 125(3): 753-765.

REGMI S, CHOI YS, CHOI YH, KIM YK, CHO SS, YOO JC \& SUH JW. 2017 . Antimicrobial peptide from Bacillus subtilis CSB138: characterization, killing kinetics, and synergistic potency. Int Microbiol 20(1): 43-53.

SANGEETHA K \& ABRAHAM ET. 2006. Chemical modification of papain for use in alkaline medium. J. Mol. Catal. B: Enzymatic 38: 171-177. 
SENBAGAM D, GURUSAMY R \& SENTHILKUMAR B. 2013. Physical chemical and biological characterization of a new bacteriocin produced by Bacillus cereus NS02. Asian Pac J Trop Med 6(12): 934-941.

SCOPES RK. 1994. Protein purification: Principles and practice. Springer-Verlang New York, $422 \mathrm{p}$.

SHARMA G, DANG S, GUPTA S \& GABRANI R. 2018. Antibacterial Activity, Cytotoxicity, and the Mechanism of Action of Bacteriocin from Bacillus subtilis GAS101. Med Princ Pract 27(2): 186-192.

STAROSTIN KV, BRYANSKAYA AV, EFIMOV VM, ROZANOV AS \& PELTEK SE. 2015. Identification of Bacillus strains by MALDI TOF MS using geometric approach. Sci Rep 5:16989.

STEIN T. 2005. Bacillus subtilis antibiotics: structures, syntheses andspecific functions. Mol. Microbiol 56(4): 845-857.

TORRES AJ, PETROSELLI G, DAZ M, ERRA-BALSELLS R \& AUDISIO MC. 2015. Bacillus subtilis subs. subtilis CBMDC3f with antimicrobial activity against Gram-positive foodborne pathogenic bacteria: UV-MALDI-TOF MS analysis of its bioactive compounds. World J Microbiol Biotechnol 31: 929-940.

VALDÉS-STAUBER N \& SCHERER S. 1994. Isolation and characterization of Linocin M18, a bacteriocin produced by Brevibacterium linens. J Appl Environ Microbiol 60(10): 3809-3814.

ZHANG X, AL-DOSSARY A, HUSSAIN M, SETLOW P \& LI J. 2020. Applications of Bacillus subtilis Spores in Biotechnology and Advanced Materials. Appl Environ Microbiol 18 86(17): e01096-20.

ZHAO P, XUE Y, GAO W, LI J, ZU X, FU D, BAI X, ZUO Y, HU Z \& ZHANG F. 2018. Bacillaceae-derived peptide antibiotics since 2000. Peptides 101: 10-16.

ZHOU Z, MENG H, LIU Y, GU JD \& LI M. 2017. Stratified Bacterial and Archaeal Community in Mangrove and Intertidal Wetland Mudflats Revealed by High Throughput 16S rRNA Gene Sequencing. Front Microbiol 8: 2148.

\section{How to cite}

CAVALINI L, JANKOSKI P, CORREA APF, BRANDELLI A \& MOTTA AS. 2021. Characterization of the antimicrobial activity produced by Bacillus sp. isolated from wetland sediment. An Acad Bras Cienc 93: e20201820. DOI 10.1590/0001-3765202120201820.
Manuscript received on November 30, 2020;

accepted for publication on August 26, 2021

\section{LUCIANI CAVALINI ${ }^{1}$}

https://orcid.org/0000-0002-0628-3713

\section{PRISCILA JANKOSKI ${ }^{1}$}

https://orcid.org/0000-0003-1204-9939

\section{ANA PAULA F. CORREA ${ }^{2}$}

https://orcid.org/0000-0001-7588-5657

\section{ADRIANO BRANDELLI ${ }^{3}$}

https://orcid.org/0000-0002-9307-6471

\section{AMANDA S. DA MOTTA ${ }^{1}$}

https://orcid.org/0000-0001-8637-3868

${ }^{1}$ Universidade Federal do Rio Grande do Sul, Departamento de Microbiologia, Imunologia e Parasitologia, Instituto das Ciências Básicas da Saúde, Rua Sarmento Leite 500, Sala 216, 90050-170 Porto Alegre, RS, Brazil

${ }^{2}$ Universidade Federal de Roraima, Programa de Pósgraduação em Recursos Naturais-PRONAT, Av. Ene Garcez, 2413, Bairro Aeroporto, 69304-000 Boa Vista, RR, Brazil

${ }^{3}$ Universidade Federal do Rio Grande do Sul, Departamento de Ciência dos Alimentos, Instituto de Ciência e Tecnologia de Alimentos, Av. Bento Gonçalves, 9500, Campus do Vale, Prédio 43.212, 91501-970 Porto Alegre, RS, Brazil

Correspondence to: Amanda de Souza da Motta E-mail:amanda.motta@ufrgs.br

\section{Author contributions}

Priscila Ribeiro Jankoski and Luciani Cavalini: Conducted the collection of sediment samples, performed the analyzes and wrote the manuscript. Ana Paula Folmer Correa: Assisted in chromatographic analysis and purification steps. Adriano Brandelli: Revised the manuscript. Amanda de Souza da Motta: conceived the idea; assistance in purification analysis and manuscript review. All authors read and approved the manuscript.

\section{(cc) BY}

